\title{
“THIS HEART'S GEOGRAPHY'S MAP": THE PHOTOGRAPHS OF WALT WHITMAN
}

\author{
ED Folsom
}

WaLt Whitman was fascinated, as no doubt we all are, with photographic images of himself. From the early 1840 s (within a couple of years after the daguerreotype process first came to America) until within a year of his death, Whitman sat for photographers, collected and commented on the results, admired certain poses and disliked others, had hundreds of copies of his favorite ones made, tolerated the middling ones, and burned some of the bad ones. Toward the end of his life, he and his friends began thinking about publishing a book or album containing a selection of the photographs. In 1889 Whitman told Horace Traubel, "If I could get a book to suit me, into which I could put the pictures to suit me, I would be happy. I wonder if it could be done?" Traubel notes that Whitman had "a great mess" of photos lying about and "had often thought to collect them," so he suggested the idea of "a Whitman gallery-a book giving W. portraits-lots-all-of them." He checked into prices for various album arrangements and reported the results to Whitman, but the poet kept putting off a decision. Other friends thought of taking up the project - William Douglas O'Connor, just before his death, had vowed to make a collection of Whitman photos ("I shall take care to have it full and complete: it would make a most remarkable presentment: I have always desired to do the thing," to which Whitman replied, "What the hell would a man want such a collection for anyway?"), and J. H. Johnston planned a book of portraits of the poet and his friends. In August of 1889, Whitman wrote to Dr. Richard Maurice Bucke about the possibility of printing a select group of photos on uniform cards and arranging them in "a good handsome fitting envelope (\& perhaps album)." At this time he even wrote up instructions to the printer specifying a run of 200 copies with gilt labeling and the title Pictures from life of $W W$; the project finally resulted in the printing of a small packet of six photos. At Whitman's death, his photographs were divided-along with his manuscripts, correspondence, notebooks, and other materials - between his three literary executors, and from there dissolved into a hopeless array of libraries and private collections. Two of his executors published some photos, but none of Whitman's associates attempted a full collection.

This special issue of the Walt Whitman Quarterly Review brings together for the first time all known photographs of Whitman. Until now, the only attempt to do this was Henry S. Saunders's privately compiled Whitman Portraits (1922) and his subsequent privately distributed Whitman Photographs (1939). Saunders made nine carbon copies of his Portraits and glued in photographic prints of the various photos, paintings, busts, etchings, and other 
likenesses of Whitman that he had collected. On the title page of his volume Saunders wrote, "Further information in regard to dates of the pictures is solicited. Many of them had to be placed at a guess." This issue of $W W Q R$ can be read as a response sixty-five years later. We can now identify some of the photos that Saunders could not, and we have added the many photosseveral of them published here for the first time-that have come to light since Saunders amassed his collection. Saunders managed to collect ninetyeight images based on photographs of Whitman; we can now offer 130. But without Saunders's work, this special issue would have been impossible. William White's brief tribute to Saunders is printed at the end of this issue, and the issue is itself a tribute to Saunders's lifelong dedication to Whitman.

Saunders initially attempted to collect all visual images of the poet, but he came to realize that the photographs were by far the most fascinating documents, as indeed they had been for Whitman. Whitman told his friends, "I find I often like the photographs better than the oils - they are perhaps mechanical, but they are honest. The artists add and deduct: the artists fool with nature. . . . I think I like the best photographs best." He would often comment about how photography was part of an emerging democratic art, how its commonness, cheapness, and ease were displacing the refined image of art implicit in portrait painting: "I think the painter has much to do to go ahead of the best photographs." For Whitman, the old hierarchy of seeing was represented by painting and sculpture, which emphasized selectivity, patience, formal structuring and composing (and a formality of posing), and which created objects that were never precisely what they portrayed but instead were distillations of reality-ideas about things. Painted portraits were for the privileged classes, and even the wealthy did not have their portraits painted regularly; the one or two they had done over a lifetime had to distill their character in an approximation that transcended time. But photographs were the property of all classes, and they allowed people to track their aging accurately, to watch themselves change step by step as they grew old. They tracked a life in time and demonstrated that life was a process of continuity and change.

Whitman's generation was the first to be able to watch itself age, to actually look back on its youth in a distant mirror. The power of photography, Whitman said, was in its "knack of catching life on the run, in a flash, as it shifted, moved, evolved." Photographs were, precisely, moments along life's continuum, were stuck in time, were in fact the sticking of time as opposed to painted portraiture which was the transcendence of life's continuum. Painting's hierarchy of selectivity and distillation gave way to photography's brash informality and quickness (within a few years the length of time required for exposure dwindled from several minutes to seconds). What may not have seemed worth a painter's time was, for the photographer, always worth a few seconds and a few cents.

No author's life in the nineteenth century was more continuously photo- 
graphed than Whitman's. (Mark Twain had more photos taken, but many of the most familiar ones were in the twentieth century.) "No man has been photographed more than I have," he once said, and many contemporary observers agreed with his assessment. At times he seemed fatigued with the profusion of images: "I have been photographed, photographed, photographed, until the cameras themselves are tired of me." Looking at the hopeless clutter of photographs scattered around him in his Camden room in the late 1880s, unable to identify the dates and circumstances of many of them, Whitman lamented, "I have been photographed to confusion." "I've been taken and taken beyond count," he said, "taken from every side-even from my blind side." At times he made it sound as if photographers had hounded him into sitting for them and had used him mercilessly: "They have photographed me all ages, sizes, shapes: they have used me for a show-horse again and again and again." His photographs, reproduced and widely distributed by various photographers and by Whitman himself, had made him something of a celebrity: "my head gets about: is easily recognized." Stumbling upon photos of himself he had forgotten had been taken, he joked, "I meet new Walt Whitmans every day. There are a dozen of me afloat. I don't know which Walt Whitman I am."

This "confusion" of Whitmans, this jocular identity crisis, often turned more serious as he thought about what all these images over the years suggested about the wholeness of his life: "It is hard to extract a man's real selfany man-from such a chaotic mass - from such historic debris." While he knew that "the man is greater than his portrait," he also knew that his photographs over a lifetime were adding up to something, were capturing a persisting quality that had never before been seen in human experience: "The human expression is so fleeting - so quick-coming and going-all aids are welcome." He carefully read and interpreted his photos, looking for clues to their individual and momentary significance, looking for ways the single images added up to a totality, ways the elements formed a compound: "I guess they all hint at the man." Most of the photos, he believed, were "one of many, only-not many in one," each picture an image that was "useful in totaling a man but not a total in itself." In a poem he wrote about a photograph, Whitman referred to the image of his face as "This heart's geography's map," and as he examined his photographs, he tried to read them like a map-a series of visible shorthand signs cast on paper that would guide him to the nature of his invisible heart. He wondered whether the photos finally demonstrated that life was "evolutional or episodical," a unified sweep of a single identity or a jarring series of new identities.

I have included substantial notes with these photographs in order to demonstrate how seriously Whitman took them as guides to the mystery of his identity. He spoke eloquently and intimately about the shifting images of himself thit his photographs manifested. Particularly toward the end of his life, he was insistent about certain qualities that he felt should and should not 
be discerned in public images of himself, and he was fascinated with and at times disturbed by some of the qualities that appeared in images he hoped to keep private. From the time he first saw daguerreotypes, Whitman was entranced by what he called the "strange fascination of looking at the eyes of a portrait," a fascination, he said, that "sometimes goes beyond what comes from the real orbs themselves." Wandering through a daguerreotype gallery in 1846, struck by the "great legion of human faces - human eyes gazing silently but fixedly upon you," he mused: "We love to dwell long upon themto infer many things, from the text they preach-to pursue the current of thoughts running riot about them." Forty years later, the gallery of faces he would be dwelling upon would be a legion of himself, and he maintained his curiosity about the text that his own fixed and gazing eyes preached over the years.

I have included in the notes the best information I could find concerning the dates of the photos and the identity of the photographers. Often these had to be guesses based on various relationships between the photos-props, dress, studio styles, etc. For easy cross-reference, I have included with those photos that appeared in Henry Saunders's Whitman Portraits the numbers that Saunders assigned to them, but I have arranged the photos in a quite different order; the new order reflects the revised dating and identification of photographers. The photos are now numbered within decades, and I have kept together photos taken by the same photographer at nearly the same time. In arriving at the identifications, I have depended on the work of a number of scholars; they are acknowledged in the bibliographic note at the end of this issue. Some of the identifications came from notes written by Horace Traubel on the backs of photographs he owned (now in various collections); his notes often key those photos to particular discussions in his long record of conversations with Whitman (With Walt Whitman in Camden). Other identifications came from my examination of Whitman's notebooks, correspondence, daybooks, and published conversations with various people; these too are listed in the bibliographic note.

Even though the identifications of the photographers are often uncertain (and, even when we know which studio took a photo, we seldom know for sure which photographer operated the camera), it is important to realize the significance of the photographic pioneers Whitman encountered. He reached maturity just as photography began to transform sight (he was twenty when the first daguerreotypes appeared in America), and he came to know some of America's leading early photographers (for example: Mathew Brady, whose photographs taught us to see war in realistic instead of heroic-romantic terms; Alexander Gardner, whose work taught us to see the frontier in realistic terms for the first time as he photographed the railroads pushing west across the plains; Napoleon Sarony and Frederick Gutekunst, whose photographs initiated the modern concept of "celebrity"). As Whitman died, photography was just entering the age of full portability; roll film and small cam- 
eras were quickly democratizing the act of photography, moving it out of the hands of skilled masters into all of our hands, making image-making far easier than even Whitman could have imagined.

Whitman anticipated the significance of photography for the development of American democracy; his poetry moved with the invention, and he learned valuable lessons from the photographers he knew. He developed an open and tough line that responded to the swivel of the head on the neck ("My head slues round on my neck") as it looked at the world; his catalogues brought reality hurtling into poetry with the same speed that photographs were cataloguing reality and bringing things that were out of the range of any single person's sight into a shared field of vision ("To me the converging objects of the universe perpetually flow"). The camera, like Whitman's poetry, democratized imagery, suggesting that anything was worth a photograph. What may not have been fit subject for a formal poet of classical education would slide effortlessly into the open forms of the democratic poet who was out to turn America into the greatest poem, a poem that would take the risks of inclusiveness: "What is commonest, cheapest, nearest, easiest, is $\mathrm{Me}, / \mathrm{Me}$ going in for my chances, spending for vast returns." For Whitman, the clutter of reality that the photograph revealed and celebrated became the stuff of his catalogues, poems embracing the vast variety of the world. Because of the significance of photography's relationship to Whitman's democratic art, and because Whitman knew and was photographed by so many of the most important early photographic artists, I have included at the back of this issue brief notes about the various photographers who took his pictures, and I have included, when available, Whitman's assessment of their work.

Numerous libraries and collections were involved in this project; major research collections dealing with Whitman and with nineteenth century American photography were queried about their holdings of Whitman photographs, and we are grateful for their helpful responses. The libraries and collections whose copies of photographs we have used are acknowledged individually in the notes. The consistency and quality of the prints are not as fine as we would wish: while a few photographs in this issue are copies of original prints, most of them are of necessity copies of copies; some of the original photographs are in very bad shape; and different libraries have quite different duplication facilities. We have used the best images we could find, given our very limited resources. We would like especially to acknowledge the help and guidance of Gay Wilson Allen, Charles E. Feinberg, Jim Perlman, William F. Stapp (National Portrait Gallery, Smithsonian Institution), Judith Zilczer (Hirshhorn Museum and Sculpture Garden, Smithsonian Institution), Randall Waldron and Kathleen Weibel (Ohio Wesleyan University, Bayley Collection). 
